\title{
PRODUCTION AND USAGE OF DIFFERENT TYPES OF ASH-CAKES FROM PEGANUM HARMALA L. (ZYGOPHYLLACEAE) IN ANATOLIA, TURKEY
}

\author{
Onur Koyuncu, Derviş Öztürk, Ismühan PotoĞLu Erkara*, \\ Ömer Koray Yaylaci and Murat Ardiç \\ Department of Biology, Faculty of Science and Art, Eskişehir Osmangazi University, \\ 26480, Meselik, Eskisehir, Turkey \\ Key words: Peganum harmala L., "Aşkar" (charcoal), Ethnobotany, Anatolia, Turkey
}

\begin{abstract}
Peganum harmala L. (Zygophyllaceae) is burned into ash-cake ("Așkar") in Emirdağ (Afyon), Middle Anatolia. The plant has been widely known as Üzerlik in Anatolia in addition to other names. In this study, both the production and usages of the ash-cake from Peganum harmala L. in Anatolia has been described. It has ethnobotanical importance in protecting silk and hair and as fumigant.
\end{abstract}

The plant Peganum harmala L. grows naturally in Turkey (Davis 1965-1985) and is a popular plant in traditional medicine. It is locally known by Askar, Üzellik, Wild Garden Rue, Ilezik, Nazarotu, Üzerik and Üzeriyh, Üzerlik (Baytop 1984, 1994). It is registered in the Turkish Pharmacopeia among the medicinal plants. The plant is known to have been used in the treatment for epilepsy, varicose veins, headaches, allergic influenza, hay fever, joint and rheumatic pains, hemorrhage, sexual potency enhancer and in pregnancy, elephantiasis and urinal incontinence/bed wetting (Prashanth and John 1999, Monsef et al. 2004, Kartal et al. 2004, Pieroni et al. 2005, Durrani and Manzoor 2006, Panhwar and Abro 2007, Zaker et al. 2007, Shahverdi et al. 2008). Furthermore, one very common use is said to be protection against the evil eye. The seeds having 'Turkish' shade of red has also led its use in red paint, according to several sources. When drunk together with Indian Hemp (Cannabis sativa L.) flowers, it is claimed that it gives the power 'to make a blind man see', increases the power of imagination, as well as boosting the effect of narcotics when supplemented. A known use in the past in Central Anatolia of its ash as soda or soap. Aşkar made from the plant is still known to be used as a cleaning material in the districts of Sivas, Tokat, Nevşehir, Kırşehir and Emirdağ.

Preparation of "Aşkar" from Peganum harmala L.: Preparation and usages of 'Aşkar' are observed during June and July months in Yeniköy (Emirdağ-Afyon) and its surroundings. The dried P. harmala L. plants with well matured fruits are cut at ground level. 5-6 sacks of the plants are collected, 2-3 of which are placed on the top of a trivet surrounded by sheep dung and burnt. The remaining 2-3 sacks of plants are thrown on to the top of the burning plants afterwards. The burning continued for 3-4 hours into ash which looks grey-black. This ash is allowed to cool for a day. Sheep dung is placed at the circumference of the ashes on the following day, and it is again burnt. After burning the grey-black ash powder reverts to a gall state that appeared as a porous black coloured and hard structure (Figs 1a-f). The name 'Aşkar' is given for this charcoal of gall. Approximately $1 \mathrm{~kg}$ of 'Aşkar' is obtained from 5-6 sacks of plants.

*Corresponding author: E-mail: ismuhan@ogu.edu.tr 

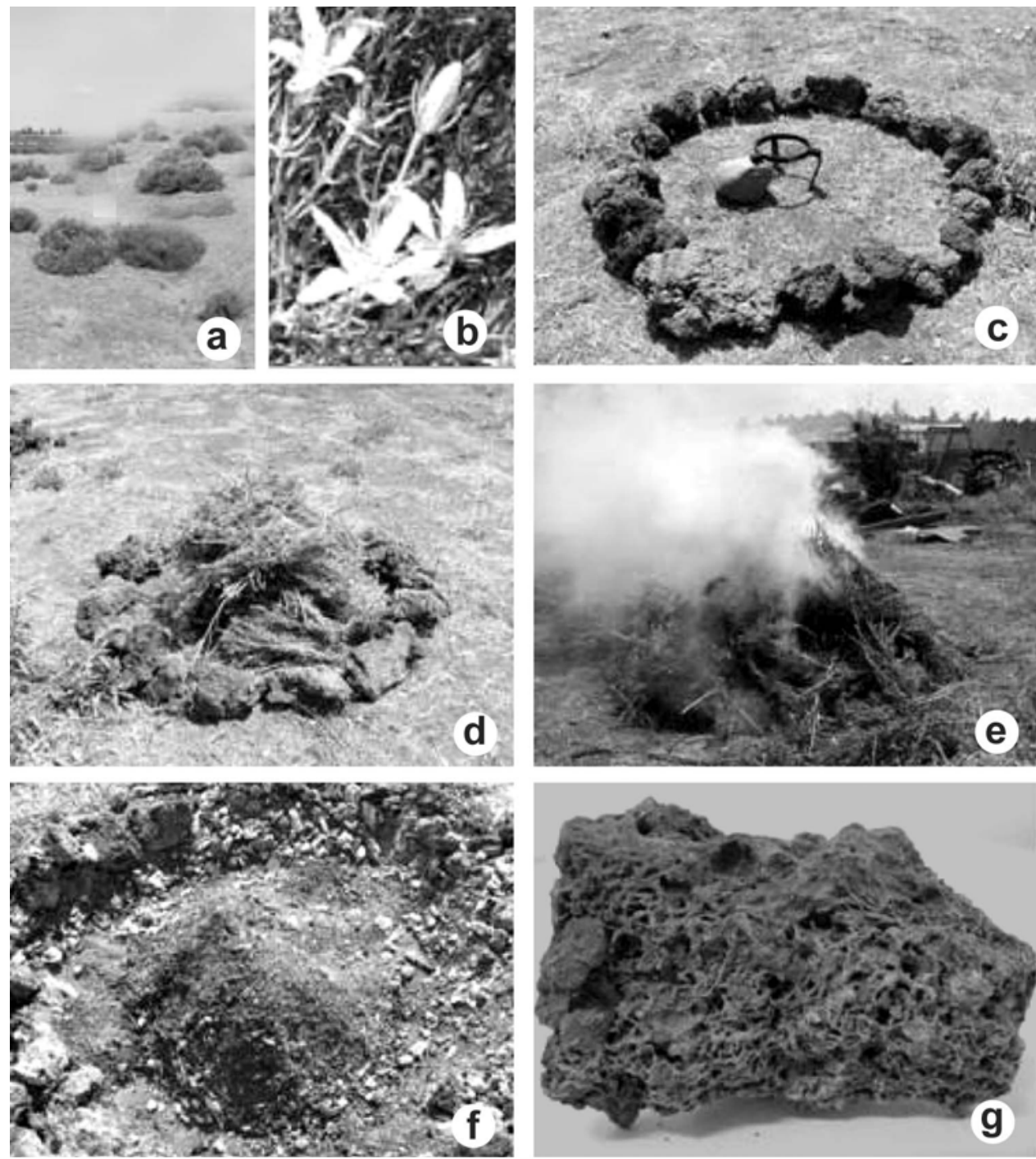

Figs 1a-f. Peganum harmala L. and preparation of "Aşkar". a. Community of P. harmala L. b. Flowering stage in plants. c-d. Preparation for ash making. e. Burning dired plants. f. Ash or charcoal accumulated. g. Final form of "Askar" made from the charcoal.

In addition to use for washing, the 'Aşkar' is used for hair and skin care. A piece, the size of a matchbox of 'Aşkar' is placed in a bucket of water and boiled, allowed to cool, and is used as green soap. Hair looks more lively and gives shiny appearance, removes dandruff and skin becomes tight. The widespread 'Aşkar' culture in this region in particular, is maintained by some people over the age of 50 . 
There is no published records on the use of $P$. harmala L. (Harmal) for hair and skin care. In this study, use of the plant in hair and skin care is reported for the first time. An investigation on the use of $P$. harmala L. (Harmal) as a homeopathic medicine may be made.

\section{References}

Baytop T. 1984. Türkiye'de bitkiler ile tedavi (Geçmişte ve Bugün), İ.Ü. yayınları No. 3255. Eczacılık Fak. No. 40. İstanbul.

Baytop T. 1994. Türkçe Bitki Adları Sözlüğü. Türk Dil Kurumu Yayınları. 508 pp.

Davis P.H. (Ed.) 1965-1985. Flora of Turkey and the East Aegean Island. Vols 1-9. Edinburgh Univ. Press, Edinburgh.

Monsef H.R., A. Ghobadi, M. Iranshahi and M. Abdollahi. 2004. Antinociceptive effects of Peganum harmala L. alkoloid extract on mouse formalin test. J. Pharm. Pharmaceut. Sci. 7(1): 65-69.

Kartal M., M.L. Altun and S. Kurucu. 2004. Peganum harmala L. (Üzerlik) Tohumlarında Harmol, Harmalol, Harmin Ve Harmalin Alkaloitlerinin Ybsk Yöntemi İle Analizi. 14. Bitkisel İlaç Hammaddeleri Toplantıs1, Bildiriler, 29-31 Mayıs 2002, Eskişehir, Eds. K.H.C. Başer ve N.Kırımer. Online Haziran 2004 ISBN 975-94077-2-8.

Pieroni A., H. Muenz, M. Akbulut, K.H.C. Başer and C. Durmuşkahya. 2005. Traditional phytotherapy and trans-cultural pharmacy among turkish migrants living in Cologne, Germany. Ethnopharmacol. 10: 69-88.

Durrani M.J. and M. Manzoor. 2006. Ethnobotanical study of some plants of S.B.K Woman University, Quetta. Pak. J. Pl. Sci. 12(1): 83-88.

Panhwar A.Q. and H. Abro. 2007. Ethnobotanical studies of Mahal Kohistan (Khirthar National Park). Pak. J. Bot. 39(7): 2301-2315.

Prashanth D. and S. John. 1999. Antibacterial activity of Peganum harmala. Fitoterapia 70: 438-439.

Shahverdi A.R., S.N. Ostad, S. Khodaee, L. Bitarafan, H.R. Monsef-Esfahani, H. Jamalifar, B. Nikavar and M. Mohseni. 2008. Antimicrobial and cytotoxicity potential of Peganum harmala smoke. Pharmacognosy Magazine 4(15): 236-240.

Zaker F., A. Oody and A. Arjmand. 2007. A study on the antitumoral and differentiation effects of Peganum harmala derivatives in combination with ATRA on leukaemic cells. Arch. Pharm. Res. 30: 844-849. 